\title{
IMPROVING THE NOTCH-RUPTURE STRENGTH OF LOW-EXPANSION SUPERALLOYS
}

\author{
D. F. Smith, E. F. Clatworthy, \\ D. G. Tipton, and W. L. Mankins \\ Huntington Alloys, Inc. \\ Huntington, West Virginia
}

Age-hardenable iron-nickel-cobalt alloys that combine high strength with controlled thermal-expansion characteristics have attractive properties for various applications at temperatures to $650^{\circ} \mathrm{C}\left(1200^{\circ} \mathrm{F}\right)$. However, the alloys have had very poor notchrupture strength unless stressed in the direction of retained warm work. Stress-rupture properties in air were further deteriorated by intergranular oxidation/stress-corrosion cracking. Through extensive research on the alloy system, those drawbacks have now been greatly reduced. A modified alloy shows much improved notch-rupture strength while retaining the desirable thermal-expansion characteristics. The improvement was brought about through lowered aluminum content, increased levels of columbium and titanium, and modified heat treatment.

INCOLOY* alloy 903 ( $38 \mathrm{Ni}, 15 \mathrm{Co}, 3 \mathrm{Cb}, 1.4 \mathrm{Ti}, 0.9 \mathrm{Al}$, bal. Fe) is an age-hardenable al loy with high strength, controlled low expansion coefficient, good thermal-fatigue resistance (1) and reduced sensitivity to high-pressure hydrogen embrittlement (2). Its properties make it attractive for gas-turbine components at temperatures up to $650^{\circ} \mathrm{C}\left(1200^{\circ} \mathrm{F}\right)$ where smooth- and notch-bar stress-rupture behavior becomes an additional property consideration.

Attaining good notch-rupture strength has long been a problem in the development of superalloys, particularly when processing or fabrication steps such as brazing expose the material to temperatures of $980^{\circ} \mathrm{C}\left(1800^{\circ} \mathrm{F}\right)$ or higher. Unfortunately, the development of low-expansion alloys for applications up to $650^{\circ} \mathrm{C}\left(1200^{\circ} \mathrm{F}\right)$ brought no roliaf in this area $(3,4)$. Instead, apparently complicated by the lack of chromium, this problem is magnified by an environmental ef fect $(2,5)$ as shown by the intergranular oxidation of the notch cross section, Fig. 1, that occurs during stressrupture testing in air.

* Trademark for products of Huntington Alloys, Inc. 


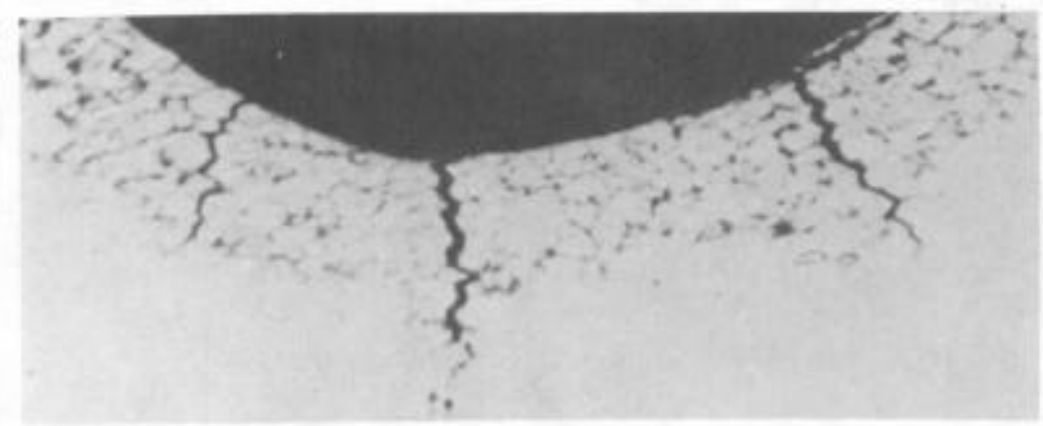

Fig. 1. Intergranular oxidation in notch of INCOLOY alloy 903 rupture specimen.

To of fset this environmental/rupture interaction In INCOLOY alloy 903 , microstructure must be controlled by thermomechanical processing (TMP) $(2,3)$. Hot-worked products must be $t i n i s h e d$ with at least $40 \%$ reduction done at or below $870^{\circ} \mathrm{C}\left(1600^{\circ} \mathrm{F}\right)$ and the subsequent elongated grain structure must be retained by holding annealing temperature to $870^{\circ} \mathrm{C}\left(1600^{\circ} \mathrm{F}\right)$ or under. The stress-rupture properties of such a structure are directional (2) with $650^{\circ} \mathrm{C}$ $\left(1200^{\circ} \mathrm{F}\right) / 100 \mathrm{~h}$ notch strength in the transverse direction only about one-third that in the longitudinal direction (221 MPa vs. $690 \mathrm{MPa})$ (32 ksi vs. $100 \mathrm{ks}$ i).

\section{ALLOY DEVELPMENT PROGRAM}

The restrlcted process temperature and resulting directionality of properties severely IImit the alloy's application. A development program was undertaken to reduce this notch-rupture/process-temperature sensitivity by modiflcations in composition or heat treatment. This program was done In three subsequent phases, each usling a test method sensitive to the stress-assistod crocking mechanism:

\footnotetext{
1. $650^{\circ} \mathrm{C}\left(1200^{\circ} \mathrm{F}\right)$ Notch-Rupture Studies

11. $540^{\circ} \mathrm{C}\left(1000^{\circ} \mathrm{F}\right)$ Bent-Beam Testing

111. $540^{\circ} \mathrm{C}\left(1000^{\circ} \mathrm{F}\right)$ Notch-Rupture Studies
}

\section{Phase $1-650^{\circ} \mathrm{C}\left(1200^{\circ} \mathrm{F}\right)$ Notch Rupture Studies}

Both heat treatment and compositional varlables were evaluated us ing primarlly comblnation-bar $\left(K_{+}=3.6\right)$ rupture tests run at $650^{\circ} \mathrm{C}\left(1200^{\circ} \mathrm{F}\right)$ at stresses ranging from $483 \mathrm{MPa}(70 \mathrm{ksl})$ to $655 \mathrm{MPa}(95 \mathrm{ks} i)$. Test sanples were thermomechan ically processed bar, 14.3-mn $(0.562-i n$.$) square, in the annealed$ plus aged condition.

Heat Treatment. Improvements in sensitivity to process temperature were determined by evaluating varlous annealing temperatures and the corresponding 
microstructures as outlined below:

\begin{tabular}{|c|c|c|}
\hline Anneal & Crain Structure & $\begin{array}{c}\text { Notch-Rupture } \\
\text { Rating } \\
\end{array}$ \\
\hline $845^{\circ} \mathrm{C}\left(1550^{\circ} \mathrm{F}\right) / 1 \mathrm{~h}$, WQ & Unrecrystallized & - \\
\hline $885^{\circ} \mathrm{C}\left(1625^{\circ} \mathrm{F}\right) / 1 \mathrm{~h}$, WQ & Partially Recryst. & $\mathrm{C}$ \\
\hline $925^{\circ} \mathrm{C}\left(1700^{\circ} \mathrm{F}\right) / 1 \mathrm{~h}, W Q$ & Recryst. ( $\leq$ ASTM $\$ 5)$ & 8 \\
\hline $1040^{\circ} \mathrm{C}\left(1900^{\circ} \mathrm{F}\right) / 0.25 \mathrm{~h}$, wQ & Recryst. (> ASTM \#5) & A \\
\hline
\end{tabular}

In the Phase 1 studies, the nolch-rupture rating refers to the maximum annealing temperature with which $650^{\circ} \mathrm{C}\left(1200^{\circ} \mathrm{F}\right)$ notch life exceeded 23 h at a stress of $483 \mathrm{MPa}$ ( $70 \mathrm{ksi}$ ) or greater. The highest rating, A, would provide the greatest latitude in process temperature during fabrication.

The aging treatment evaluated was primarily a double age of $720^{\circ} \mathrm{C}$ $\left(1325^{\circ} \mathrm{F}\right) / 8 \mathrm{~h}$, furnace cool at $55^{\circ} \mathrm{C}\left(100^{\circ} \mathrm{F}\right) / \mathrm{h}$ to $620^{\circ} \mathrm{C}\left(1150^{\circ} \mathrm{F}\right) / 8 \mathrm{~h}$, air cool. In a few cases, Initial aging temperature ranged between $680^{\circ} \mathrm{C}\left(1250^{\circ} \mathrm{F}\right)$ and $760^{\circ} \mathrm{C}\left(1400^{\circ} \mathrm{F}\right)$ or three-step ages were included with intermediate aging temperature at $760^{\circ} \mathrm{C}$ to $790^{\circ} \mathrm{C}\left(1400^{\circ} \mathrm{F}\right.$ to $\left.1450^{\circ} \mathrm{F}\right)$ for times up to $8 \mathrm{~h}$.

Compositional Modifications. About 110 laboratory-scale heats were tested, including single-element and factorial investigations of $\mathrm{Al}, \mathrm{Cb}, \mathrm{Ti}$, $\mathrm{Cr}, \mathrm{Mn}, \mathrm{Cu}, \mathrm{Mo}, \mathrm{B}, \mathrm{C}, \mathrm{V}, \mathrm{Zr}, \mathrm{Hf}, \mathrm{Si}, \mathrm{Ce}$, and La. Table 1 lists those factors found to reduce the process-temperature sensitivity of this alloy system. Included are comments about the effects these adjustments would have on other properties.

With the base composition, overaging heat treatments were only marginally effective as were higher titanium or columbium, increased boron (above .010\%) and restricted al uminum $(0.4 \%$ to $0.6 \%)$. The addition of up to $2 \%$ hafnium produced notch ductility with a $925^{\circ} \mathrm{C}\left(1700^{\circ} \mathrm{F}\right)$ anneal but not with a $1040^{\circ} \mathrm{C}$ $\left(1900^{\circ} \mathrm{F}\right.$ ) anneal. As shown in Table 2 , the most substantial improvements, i.e., good notch strength with a $1040^{\circ} \mathrm{C}\left(1900^{\circ} \mathrm{F}\right)$ anneal, were obtained by either the addition of about $2 \%$ or more chromium or by restricting aluminum to levels less than $0.4 \%$. Chromium additions to this alloy system did result in altered thermal expansion behavior, specifically lowering the inflection temperature and increasing the expansion coefficient.

Table 1. Factors Reducing Sensitivity of Notch-Rupture Strength to Process Temperature

\begin{tabular}{l|l|c|l}
\hline Factor & Level & Rating & \multicolumn{1}{c}{ Comments } \\
\hline Heat & $\begin{array}{c}\text { Overaging, } \\
\text { Intermediate Age }\end{array}$ & $\mathrm{C}$ & Decreases strength. \\
Treat & $\mathrm{C}$ & Decreases ductility \& wel dability. \\
$\mathrm{Ti}$ & Over $1.6 \%$ & $\mathrm{C}$ & Decreases ductility. \\
$\mathrm{Cb}$ & Over $4.0 \%$ & $\mathrm{C}$ & Harms hot working \& wel ding. \\
$\mathrm{B}$ & Over $0.01 \%$ & $\mathrm{C}$ & Slightly decreases strength. \\
$\mathrm{Al}$ & 0.4 to $0.6 \%$ & $\mathrm{~B}$ & Costly Scale-up problems. \\
$\mathrm{Hf}$ & to $2 \%$ & $\mathrm{~A}$ & Alters thermal expansion. \\
$\mathrm{Cr}$ & Over $2 \%$ & $\mathrm{~A}$ & Decreases strength. \\
$\mathrm{Al}$ & Under $0.4 \%$ &
\end{tabular}


Table 2. Effect of Aluminum and Chromium on Stress-Rupture Properties of $650^{\circ} \mathrm{C}\left(1200^{\circ} \mathrm{F}\right)$

\begin{tabular}{|c|c|c|c|c|c|c|c|c|}
\hline \multirow[b]{2}{*}{ Al, $\ldots$} & \multirow[b]{2}{*}{$\mathrm{Cr}, \mathrm{B}$} & \multicolumn{2}{|c|}{ Anneal ${ }^{\text {a }}$} & \multicolumn{2}{|c|}{ stress, D $\mathrm{MPa}$} & \multirow{2}{*}{$\underset{h}{\operatorname{Lif}}$} & \multirow{2}{*}{$\underset{b}{E}$} & \multirow{2}{*}{$\begin{array}{l}\text { RA, } \\
x\end{array}$} \\
\hline & & ${ }^{2} \mathrm{C}$ & h & Tniflat & Final & & & \\
\hline 0.7 & - & 925 & 1 & 483 & 483 & 4.6 & In No & \\
\hline 0.7 & 3.8 & 925 & 1 & 483 & 483 & 109.1 & In Not & \\
\hline 0.7 & 3.8 & 1040 & 0.25 & 566 & $827^{\mathrm{C}}$ & 1101.6 & 6 & 25 \\
\hline 0.3 & - & 925 & 1 & 483 & 724 & 129.0 & 10 & 10 \\
\hline 0.3 & - & 1040 & 0.25 & 552 & 690 & 101.3 & 4.5 & 5.5 \\
\hline 0.08 & - & 925 & 1 & 483 & 552 & 64.4 & 14 & 45 \\
\hline 0.08 & - & 1040 & 0.25 & 552 & 586 & 53.5 & 8 & 15 \\
\hline
\end{tabular}

${ }^{\mathrm{a}} \mathrm{All}$ samples water quenched of ter anneal and aged $720^{\circ} \mathrm{C} / 8 \mathrm{~h}, \mathrm{FC} 55^{\circ} \mathrm{C} / \mathrm{h}$ to $620^{\circ} \mathrm{C} / 8 \mathrm{~B}, \mathrm{AC}$.

After $48 \mathrm{~h}$, stress increased $35 \mathrm{MPa}$ every $12 \mathrm{~h}$ except as noted.

CAtter $100 \mathrm{~h}$, stress increased $35 \mathrm{MPa}$ every $12 \mathrm{~h}$.

Lowering aluminum at the base titanium and columbium levels lowered roon-temperature tenstie and yield strengths and $650^{\circ} \mathrm{C}\left(1200^{\circ} \mathrm{F}\right)$ smooth-bar strongth while increasing rupture ductility.

Phase 11 - 5 AGBO Testing at $540^{\circ} \mathrm{C}\left(1000^{\circ} \mathrm{F}\right)$

Further investigation of the variables found effoctive in roducing notch-rupture sensitivity to process temperature was done with a twopoint-loaded, bent-beam test. Fig. 2 shows the specimen and its mounting arrangement. Other researchers (6) found this test, known as SAGBO (stress= accelerated grain-boundary oxidation), effective in measuring the stresscracking behavior of INCOLOY al loy 903 in air at $425^{\circ} \mathrm{C}$ to $650^{\circ} \mathrm{C}\left(800^{\circ} \mathrm{F}\right.$ to $\left.1200^{\circ} \mathrm{F}\right)$. The $540^{\circ} \mathrm{C}\left(1000^{\circ} \mathrm{F}\right)$ temperature was selected for Phase 11 and subsequent Phase 111 studies because it was shown to be more critical for this oxidation-cracking mechanist.

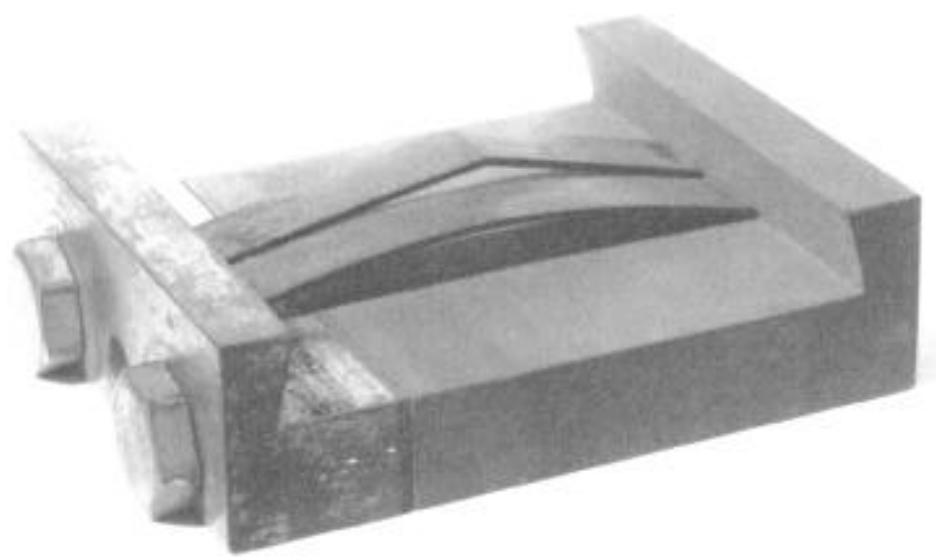

Fig. 2. Specimens in fixture for stress-accelerated grain-boundary oxidation (SAGBO) test. 


\section{F. Smith et a $1 . / 525$}

Testing was done on $12.7-\mathrm{mm}(0.500-\mathrm{in}$.$) wide transverse specimens cut$ from 1.52-mm (0.060-in.) gage $\times$ 95.2-mm (3.75-in.) width cold-rolled strip. The ends of the specimens were chisel pointed to a length calculated from the ASTM G-39-73 formula for bent beams.

A factorial melt program was done to further demonstrate the effects of aluminum, chromium, and columbium on the oxidation-related cracking of this alloy. One melt having $3.8 \%$ chromium and $0.2 \%$ aluminum was also included in this analysis. Samples annealed at $1040^{\circ} \mathrm{C}\left(1900^{\circ} \mathrm{F}\right) / 0.25 \mathrm{~h}$, WQ, and given the $720^{\circ} \mathrm{C}\left(1325^{\circ} \mathrm{F}\right)$ double age were tested at $540^{\circ} \mathrm{C}\left(1000^{\circ} \mathrm{F}\right)$ and a pseudo stress of $1034 \mathrm{MPa}(150 \mathrm{ksi})$.

The SAGBO results listed in Table 3 confirm findings from Phase 1: decreased aluminum content improved stress-corrosion-cracking resistance. The melts with less than 0.1\% aluminum showed a substantial gain in SAGBO Iife. Columbium seemed to show a slight positive effect on SAGBO life as it did in Phase 1. The effect of chromium was more obscure but seemed to support the benefits found in Phase I at high aluminum and $3 \%$ columbium.

The regression equation developed from these data shows a strong negative aluminum effect, a more-complex chromium and aluminum/chromium interaction, and a slight positive columbium effect. For $540^{\circ} \mathrm{C}\left(1000^{\circ} \mathrm{F}\right) / 1034 \mathrm{MPa}(150 \mathrm{ksi})$ test conditions:

$$
\text { SAGBO Life, } \begin{aligned}
\mathrm{h}= & -87.92-141.3(\log \mathrm{Al})+3.609(1 / \mathrm{Cr}) \\
& -3.428 \mathrm{NI} / \mathrm{Cr}+32.54(\mathrm{Al} \times \mathrm{Cr})+21.39(\mathrm{Cb})
\end{aligned}
$$

A comparison of the ef fects of aluminum and chromium on notch strength at $650^{\circ} \mathrm{C}\left(1200^{\circ} \mathrm{F}\right)$ with those obtained from this $540^{\circ} \mathrm{C}\left(1000^{\circ} \mathrm{F}\right)$ SAGBO regression equation show an interesting parallel. In Fig. 3 the alloys indicated by darkened symbols had a notch 1 ife of less than $10 \mathrm{~h}$ at $650^{\circ} \mathrm{C} / 483 \mathrm{MPa}\left(1200^{\circ} \mathrm{F} / 70\right.$ ksi) when annealed at $925^{\circ} \mathrm{C}\left(1700^{\circ} \mathrm{F}\right)$ or higher. Those represented by the open symbols would exceed 48 -h notch life.

Table 3. SAGBO Results ${ }^{\mathrm{a}}$ at $540^{\circ} \mathrm{C}\left(1000^{\circ} \mathrm{F}\right)$

\begin{tabular}{|c|c|c|c|}
\hline $\mathrm{Cb}, \%$ & $A 1, \%$ & $\begin{array}{c}\text { Cracking } \\
0 \% \mathrm{Cr}\end{array}$ & $\frac{\mathrm{me}, \mathrm{h}, \mathrm{at}}{1.8 \% \mathrm{Cr}}$ \\
\hline $\begin{array}{l}3 \\
3 \\
3 \\
4 \\
4 \\
4\end{array}$ & $\begin{array}{c}<0.1 \\
0.25 \\
0.85 \\
<0.1 \\
0.25 \\
0.85\end{array}$ & $\begin{array}{c}294 \\
95^{\mathrm{b}} \\
15^{\mathrm{b}} \\
227.8^{\mathrm{b}} \\
129.3 \\
78.5\end{array}$ & $\begin{array}{r}79.6 \\
56.1 \\
56.1 \\
205.2 \\
75.0 \\
56.1\end{array}$ \\
\hline
\end{tabular}

and $1034 \mathrm{MPa}$ (150 ksi) Pseudo Stress

additional sample containing $3.0 \% \mathrm{Cb}$, $0.2 \% \mathrm{Al}$, and $3.8 \% \mathrm{Cr}$ cracked in $115 \mathrm{~h}$. $\mathrm{b}_{\mathrm{Cr}}$ of $0.19 \%$ to $0.33 \%$. 


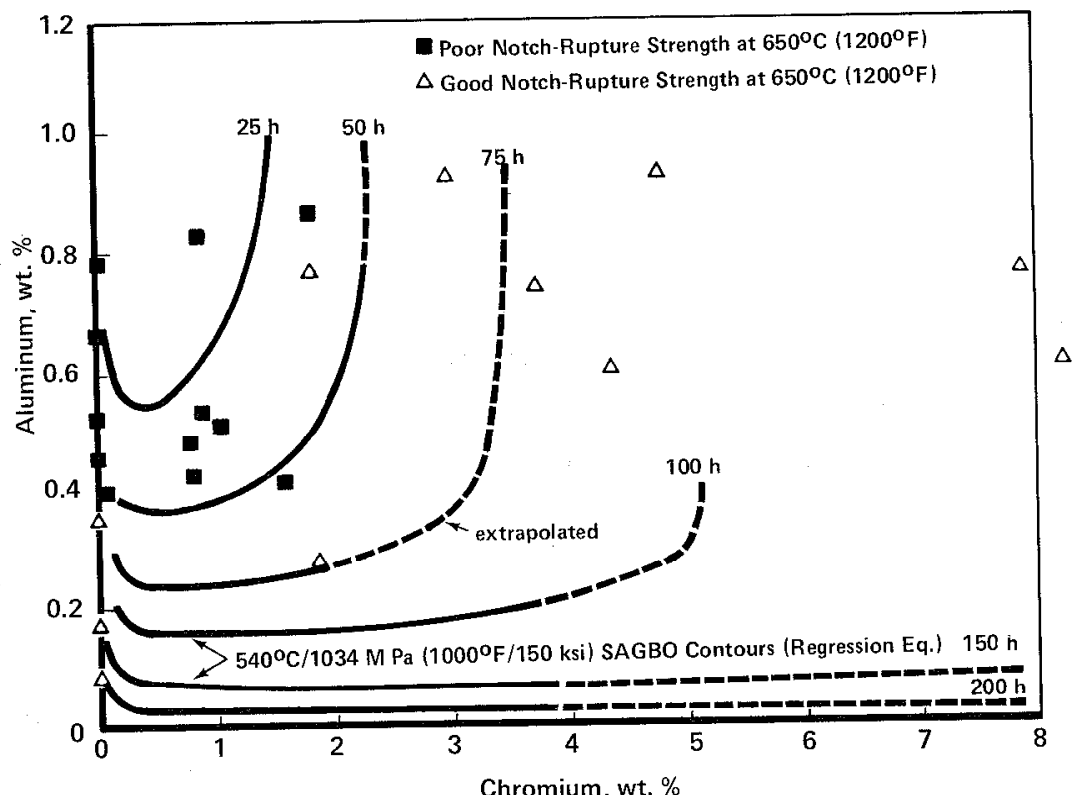

Fig. 3. Effect of aluminum and chromium on notch-rupture strength at $650^{\circ} \mathrm{C}$ $\left(1200^{\circ} \mathrm{F}\right)$.

Fig. 3 also includes isochronous $540^{\circ} \mathrm{C}\left(1000^{\circ} \mathrm{F}\right)$ SAGBO contours calculated from the regression equation above (at $3 \%$ columbium). This figure illustrates that lowering aluminum is the most effective way of improving resistance to stress-corrosion cracking and indicates that compositions having a $540^{\circ} \mathrm{C}$ $\left(1000^{\circ} \mathrm{H}\right) \mathrm{SAGBO}$ Iife greater than $75 \mathrm{~h}$ should have good $650^{\circ} \mathrm{C}\left(1200^{\circ} \mathrm{F}\right)$ notch strength.

\section{Phase $111-540^{\circ} \mathrm{C}\left(1000^{\circ} \mathrm{F}\right)$ Notch-Rupture Studies}

Since both the $540^{\circ} \mathrm{C}\left(1000^{\circ} \mathrm{F}\right)$ SAGBO and $650^{\circ} \mathrm{C}\left(1200^{\circ} \mathrm{F}\right)$ notch-rupture results were similar, particularly the improvements with lowered al uminum, al loy development was narrowed to optimize the $540^{\circ} \mathrm{C}\left(1000^{\circ} \mathrm{F}\right)$ notch strength in a chromium-free alloy having low aluminum and high columbium. A 14-kg $(31-i b)$ melt with $0.02 \%$ aluminum and $4.3 \%$ columbium was processed to a flat 16-mm (0.62-in.) thick and 102-mm (4-in.) wide. Initial stress-rupture testing was done in the long transverse direction at $540^{\circ} \mathrm{C}\left(1000^{\circ} \mathrm{F}\right)$ and $690 \mathrm{MPa}$ (100 ksi).

Effect of Annealing. Sensitivity to process temperature was measured by varying the annealing temperature from an unrecrystallizing anneal at $925^{\circ} \mathrm{F}$ $\left(1700^{\circ} \mathrm{F}\right.$ ) (with this composition) to a grain-coarsening anneal at $1040^{\circ} \mathrm{C}$ $\left(1900^{\circ} \mathrm{F}\right)$. All samples were given the $720^{\circ} \mathrm{C}\left(1325^{\circ} \mathrm{F}\right)$ double age. 
Table 4 shows that the unrecrystallized, low-al uminum alloy would have a transverse notch strength at $540^{\circ} \mathrm{C}\left(1000^{\circ} \mathrm{F}\right)$ of over $690 \mathrm{MPa}(100 \mathrm{ksi})$, compared with $310 \mathrm{MPa}$ (45 ksi) for alloy 903 . However, even with the low-aluminum alloy, recrystallizing anneals were extremely detrimental to notch strength.

Effects of Overaging. To improve the transverse $540^{\circ} \mathrm{C}\left(1000^{\circ} \mathrm{F}\right)$ notch strength of recrystallized material, the benefits of overaging were examined. Heat treatments included varlous double ages of 720 to $815^{\circ} \mathrm{C}\left(1325\right.$ to $\left.1500^{\circ} \mathrm{F}\right)$, intermediate ages of 775 to $885^{\circ} \mathrm{C}\left(1425\right.$ to $\left.1625^{\circ} \mathrm{F}\right)$, and furnace-cooling treatments (7). Al so investigated were treatments of 815 to $870^{\circ} \mathrm{C}(1500$ to $1600^{\circ} \mathrm{F}$ ) applied before annealing.

Overaging did considerably boost the transverse notch strength of recrystallized material as shown by the two examples at the bottom of Table 4 . The tradeoff of room-temperature tensile properties resulting from such overaging is illustrated in Table 5. Even with the $775^{\circ} \mathrm{C}\left(1425^{\circ} \mathrm{F}\right)$ overage, room-temperature strength exceeded that of, for example, INCONEL* alloy X-750.

Table 4. Effect of Annealing Temperature and Overaging on Transverse Rupture Properties at $540^{\circ} \mathrm{C}\left(1000^{\circ} \mathrm{F}\right)^{\mathrm{a}}$

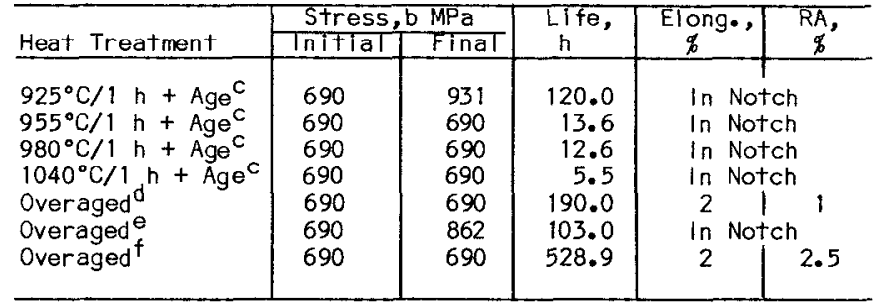

aTests on 16-mm x 102-mm hot-rolled flat having $37 \mathrm{Ni}, 14 \mathrm{Co}$, $4.4 \mathrm{Cb}, 1.5 \mathrm{Tl}, .02 \mathrm{Al}$, bal. Fe. bAfter $48 \mathrm{~h}$, stress increased $35 \mathrm{MPa}$ every $12 \mathrm{~h}$. $\mathrm{C} 720^{\circ} \mathrm{C} / 8 \mathrm{~h}, \mathrm{FC} 55^{\circ} \mathrm{C} / \mathrm{h}$ to $620^{\circ} \mathrm{C} / 8 \mathrm{~h}$, AC. d $845^{\circ} \mathrm{C} / 4 \mathrm{~h}, A C ; 980^{\circ} \mathrm{C} / 1 \mathrm{~h}, \mathrm{FC} 55^{\circ} \mathrm{C} / \mathrm{h}$ to $595^{\circ} \mathrm{C}, \mathrm{AC}$, plus " $\mathrm{C}$ " above.

e $980^{\circ} \mathrm{C} / 1 \mathrm{~h}$, WQ; $775^{\circ} \mathrm{C} / 8 \mathrm{~h}, F C 55^{\circ} \mathrm{C} / \mathrm{h}$ to $620^{\circ} \mathrm{C} / 8 \mathrm{~h}, A C$.

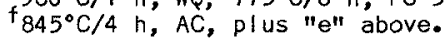

Table 5. Effect of Overaging on Room-Temperature Properties

\begin{tabular}{l|c|c|c|c}
\hline Heat Treatment & $\begin{array}{c}\text { Yield Strength } \\
(0.2 \% \text { Offset) } \\
\mathrm{MPa}\end{array}$ & $\begin{array}{c}\text { Tensile } \\
\text { Strength, } \\
\mathrm{MPa}\end{array}$ & $\begin{array}{c}\text { Elonga- } \\
\text { tion, } \%\end{array}$ & $\begin{array}{c}\text { Area } \\
\text { Reduct., } \%\end{array}$ \\
\hline $980^{\circ} \mathrm{C} / 1 \mathrm{~h},+\mathrm{Age}^{\mathrm{a}}$ & 1103 & 1310 & 18 & 35 \\
Overaged & 1000 & 1241 & 16 & 25 \\
$980^{\circ} \mathrm{C} / 1 \mathrm{~h},+$ Overaged $^{\mathrm{c}}$ & 862 & 1207 & 12 & 18 \\
\hline
\end{tabular}

a $720^{\circ} \mathrm{C} / 8 \mathrm{~h}, \mathrm{FC} 55^{\circ} \mathrm{C} / \mathrm{h}$ to $620^{\circ} \mathrm{C} / 8 \mathrm{~h}$, AC.

b $980^{\circ} \mathrm{C} / 1 \mathrm{~h}$, FC $55^{\circ} \mathrm{C} / \mathrm{h}$ to $595^{\circ} \mathrm{C}, A C$, plus "a" above.

$\mathrm{C} 775^{\circ} \mathrm{C} / 8 \mathrm{~h}$, FC $55^{\circ} \mathrm{C} / \mathrm{h}$ to $620^{\circ} \mathrm{C} / 8 \mathrm{~h}, \mathrm{AC}$. 
Typlcal microstructures of overaged material are shown in Fig. 4. The structures In a, b, and c illustrate the effects of increasing hardener content. The amount of $\mathrm{Ni}_{3} \mathrm{Cb}$ (delta) and $\mathrm{Ni}_{3} \mathrm{Tl}$ (eta) Increases with hardener levels of the appropriate elements. Precipltate decoration occurs on present and prior structural features. The amount of gamma prime, $\mathrm{Ni}_{3}(\mathrm{Cb}, \mathrm{TH}, \mathrm{Al})$, while not visible, is directly influenced by the precipitates that form on overaging.

Figure $4 d$ shows the ef fects of a low-temperature aging treatment. The amount of the rod-morphology precipitate is decreased and the longer specles $\left(\mathrm{Ni}_{3} \mathrm{Cb}\right)$ predominates. The amount of hardener avallable for gamma prime precipitation is increased.

Regression Analysls. To further assess variables influencing the notch strength of recrystal lized, overaged material at $540^{\circ} \mathrm{C}\left(1000^{\circ} \mathrm{F}\right)$, a I inear regression analysis was conducted. The data base represented various hot-rollad and forged products from twelve laboratory-scale melts and one

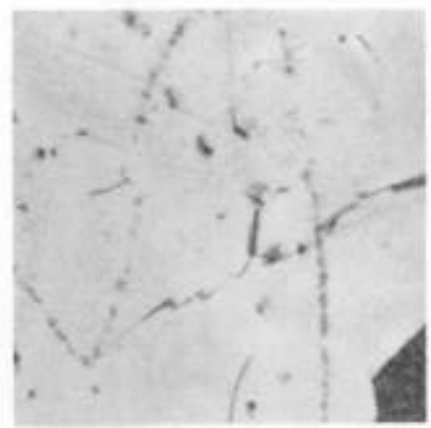

a

b
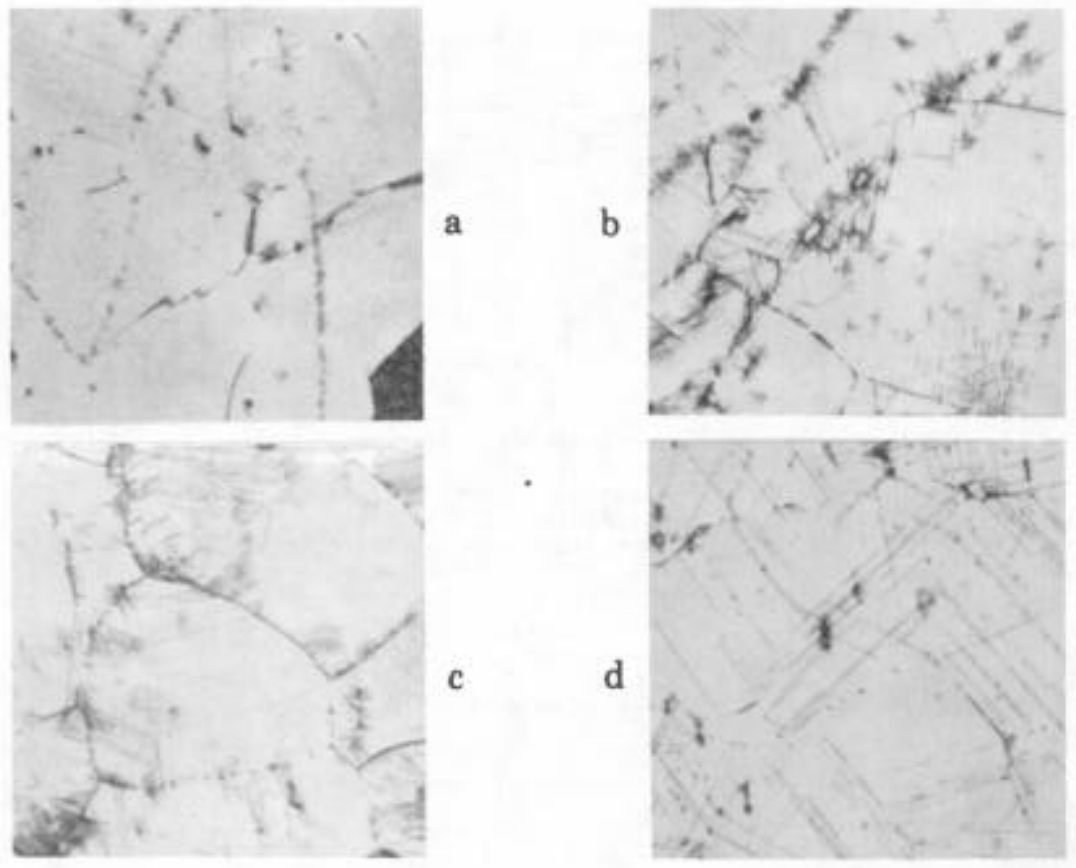

Fig. 4. Microstructures $(500 \times)$ of material with different hardener contents. (a) Low hardener content: $3.85 \% \mathrm{Cb}, 1.38 \% \mathrm{TI}, 0.02 \% \mathrm{Al}$. (b) Medium hardener content: $5.0 \mathrm{Cb}, 1.36 \mathrm{TI}, 0.01 \mathrm{Al}$. (c) HIgh hardener content: $5.04 \mathrm{Cb}, 1.68$ $\mathrm{Ti}, 0.02 \mathrm{Al}$. (d) Same as (c) but with the $720^{\circ} \mathrm{C}\left(1325^{\circ} \mathrm{F}\right)$ aging treatment instead of the $775^{\circ} \mathrm{C}\left(1425^{\circ} \mathrm{F}\right)$ overaging treatment given (a), (b), and (c). Etchant: phosphoric electrolytic. 
commercial melt. The aluminum, columbium, and titanium contents were not completely orthogonal, but reasonable compositional ranges were represented within the area of low al uminum and high columbium. Test data were from longitudinal or long transverse specimens depending on the product.

Anneal ing treatments were $955^{\circ} \mathrm{C}\left(1750^{\circ} \mathrm{F}\right) / 1 \mathrm{~h}$, WQ, $980^{\circ} \mathrm{C}\left(1800^{\circ} \mathrm{F}\right) / 1 \mathrm{~h}$, WQ, or $1040^{\circ} \mathrm{C}\left(1900^{\circ} \mathrm{F}\right) / 0.25 \mathrm{~h}$, WQ. A preannealing treatment of $845^{\circ} \mathrm{C}\left(1550^{\circ} \mathrm{F}\right) / 4$ $h, A C$ was included in some cases. The overaging treatment was either the furnace cool or the $775^{\circ} \mathrm{C}\left(1425^{\circ} \mathrm{F}\right)$ double age shown in the examples in Table 4.

Table 6 shows the final regression equation selected based on the data fit. Given the nature of the notch-rupture test, particularly with an alloy in which fracture is related to outer fiber stress, the $71 \%$ correlation coefficient $\left(r^{2}\right)$ is very good. All terms were significant at less than the $1 \%$ level except pretreatment $(1 \%<\alpha<5 \%)$.

Even though restricted to a range below $0.15 \%$, al uminum continued to show a negative effect on $540^{\circ} \mathrm{C}\left(1000^{\circ} \mathrm{F}\right)$ notch $1 \mathrm{ife}$. Columbium and titanium both showed a positive ef fect probably resulting from the increased intergranular precipitates previously discussed. A directionality effect still existed, but it was less than halt an order of magn itude compared with two to three orders of magnitude difference in life for the unrecrystallized original alloy.

Heat treatment and grain structure effects showed that (a) the preanneal treatment had a slight positive effect, (b) the $775^{\circ} \mathrm{C}\left(1425^{\circ} \mathrm{F}\right.$ ) treatment (more-overaged condition) gave half an order of magnitude advantage over the furnace-cool treatment, and (c) finer grain structures increased notch life.

Table 6. Regression Equation ${ }^{a}$ for Notch-Rupture $\mathrm{Life}$ at $540^{\circ} \mathrm{C}\left(1000^{\circ} \mathrm{F}\right)$ and $690 \mathrm{MPa}(100 \mathrm{ksi})$

\begin{tabular}{|c|c|c|}
\hline Variable & Min in um & Maximum \\
\hline $\begin{array}{l}\text { Columbium } \\
\text { Titanium } \\
\text { Aluminum } \\
\text { Test Orientation (T.O.) } \\
\text { Pretreatment (P.T.) } \\
\text { Heat Treatment (H.T.) } \\
\text { Grain Size (G.S.) }\end{array}$ & $\begin{array}{l}3.91 \% \\
1.11 \% \\
0.01 \% \\
1 \text { (Transverse) } \\
0 \text { (None) } \\
1^{b} \\
\text { ASTM } 4\end{array}$ & $\begin{array}{l}5.54 \% \\
1.56 \% \\
0.14 \% \\
2(\text { Long }) \\
1\left(845^{\circ} \mathrm{C} / 4 \mathrm{~h}\right) \\
2^{\mathrm{C}} \\
\text { ASTM } 7\end{array}$ \\
\hline
\end{tabular}

$a_{45}$ observations, correlation $\left(r^{2}\right)=0.71$.

b Anneal, $\mathrm{FC} 55^{\circ} \mathrm{C} / \mathrm{h}$ to $595^{\circ} \mathrm{C}, \mathrm{AC} ; 720^{\circ} \mathrm{C} / 8 \mathrm{~h}, \mathrm{FC} 55^{\circ} \mathrm{C} / \mathrm{h}$ to $620^{\circ} \mathrm{C} / 8 \mathrm{~h}, \mathrm{AC}$.

$c_{\text {Anneal, }}$ WQ; $775^{\circ} \mathrm{C} / 8 \mathrm{~h}, \mathrm{FC} 55^{\circ} \mathrm{C} / \mathrm{h}$ to $620^{\circ} \mathrm{C} / 8 \mathrm{~h}, \mathrm{AC}$. 
SUMMARY

The notch-rupture strength of commercial age-hardenable low-expansion alloys is sensitive to test environment. Use of these alloys is restricted because of the thermomechanical processing and directionality required to develop good longitudinal notch strength. An alloy-development program has shown that:

1. Restricting aluminum content to levels below $0.2 \%$ improves the intergranular oxidation resistance and related notch-rupture strength.

2. With the low-al uminum alloy, both overaging and increasing columbium and titanium levels provide a further benefit to notch strength.

This work has resuited in a new commerclal alloy, INCOLOY alloy $903 \mathrm{~A}$, that has greatly improved notch-rupture strength while retaining the low expansion coefficient of the original material.

\section{REFERENCES}

1. H. L. Eiselstein and J. K. Bell, "New Ni-Fe-Co Alloys Provide Constant Modulus + High-Temperature Strength," Materials in Design Engineering, November, 1965.

2. H. W. Carpenter, "Alloy 903 Helps Space Shuttle Fly," Metal Progress, Aug., 1976, pp. 25-29.

3. D. F. Smith and D. E. Wenschhof, "Effects of Test Atmosphere and Thermo-Mechanical Processing on the Stress Rupture Properties of INCOLOY al loy 903," unpublished presontation, Materials Scionce Symposium, Detroit, 1974.

4. D. R. Muzyka, C. R. Whitney, and D. K. Schlosser, "Physical Metallurgy and Properties of New Controlled Expansion Superalloy," Journal of Metals, July, 1975, pp. 11-15.

5. Unpublished Communication, General Electric Jet Engine Division, Evendale, Ohio.

6. D. F. Smith and E. F. Clatworthy, "Heat Treatment of Nickel Alloys," US Patent No. 3,871,928, March 18, 1975. 